Pak. j. sci. ind. res. Ser. B: biol. sci. 2021 64B(2) 126-135

\title{
Impact of Heavy Metal Stress on Antioxidant Mechanisms of Avicennia marina (Forsk.) and Rhizophora mucronata Lamk.
}

\author{
Samrina Shams ${ }^{a *}$, Sarwat Ismail ${ }^{\text {b }}$,Muhammad Faheem Siddiqui ${ }^{a}$, Muhammad Azeem ${ }^{\text {a }}$, \\ Muhammad Saifullah a and Fayyaz Rasool ${ }^{\mathrm{c}}$ \\ ${ }^{a}$ Department of Botany, University of Karachi, Karachi, Pakistan

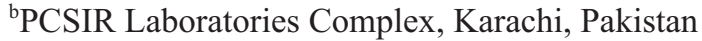 \\ ${ }^{\mathrm{c}}$ Karachi Port Trust, Karachi, Pakistan
}

(received April 2, 2019; revised January 22, 2020; accepted September 18, 2020)

\begin{abstract}
Mangrove species are growing in exposed areas which have heavy metal contamination. The safeguard the mangrove ecosystem, it is important to understand their antioxidant responses to heavy metal toxicity. The goal of this study was to determine the effect of multi-heavy metals i.e. ( $\mathrm{Pb}, \mathrm{Cd}, \mathrm{Cr}$ and $\mathrm{Hg}$ ) on two mangrove plants Avicennia marina and Rhizophora mucronata of Indus delta via investigating their antioxidative defence mechanism of leaves and roots. In this regard mangrove seedlings of both species were treated with five different concentrations of four heavy metals and different time durations $(15,30$, 45 and 60 days) for ascorbate peroxidase, catalase and superoxide dismutase in leaves and root tissues. The findings indicate that the heavy metals have significantly altered the antioxidant enzyme activities with respect of metals concentration and duration of exposure. With extended exposure higher antioxidant activities was observed in metal treated roots and leaves at higher concentrations. A pronounced stimulation $(\mathrm{P}<0.001)$ of CAT activity in both roots and leaves of $A$. marina occurred after 15 days of stress $(38.3$ and $26.6 \mu \mathrm{mol} / \mathrm{mg}$ protein $/ \mathrm{min}$ ) at $1 \mathrm{MHM}$. Our analysis also found that roots have shown greater activity in protecting against reactive oxygen species (ROS). Among the roots of two mangroves SOD activity in A. marina showed better tolerance towards metals stress $(9.26 \mathrm{U} / \mathrm{mg}$ protein at $15 \mathrm{MHM})$ compare to R. mucronata (6.09 U/mg protein at $10 \mathrm{MHM}$ ). APX showed maximum stimulation at $20 \mathrm{MHM}$ in leaves $(19.130 \mu \mathrm{mol} / \mathrm{mg}$ protein $/ \mathrm{min})$ and at $10 \mathrm{MHM}$ in roots $(19.02 \mu \mathrm{mol} / \mathrm{mg}$ protein $/ \mathrm{min})$ of $A$. marina after 30 days metals treated plant. Hence, it confirms that the antioxidative defence system plays a critical role in A. marina and R. mucronata to tolerate the multiple heavy metals stress. However, A. marina showed greater antioxidant activity especially catalyst enzyme activity as compared to $R$. mucronata, which is well evident by its dominancy in the region.
\end{abstract}

Keywords: mangroves, multiple heavy metals, oxidative stress, antioxidants

\section{Introduction}

The mangrove is the planet's most important and organically dynamic ecosystem because it provides human society seaside living spaces and coastal ecosystem supplies and administrations (Giri et al., 2010). These forests are the source of living for a large number of human beings around the world by providing wood for fuel, charcoal and timber as well as areas for fishing. They act as nurseries for the marine fauna, protect and stabilize shoreline and perform protective mechanism against Tsunamis, erosion and flooding and storm surges in the coastal zones (Ismail et al., 2014). Despite playing a crucial role, this ecosystem is continuously subjected to severe degradation due to many factors like industrialization, urbanization, overharvesting and grazing,

*Author for correspondence;

E-mail: samrinahmedpk@gmail.com over exploitation for fuel and fodder, tourism, aquaculture and pollution.

Mangrove ecosystems act as a sink of bio-chemical pollutants, but now have converted into a source of pollution. Heavy metals serve as most lethal contaminants in the mangrove biological ecosystem due to its toxicity, bioaccumulation problems and long resistance time in food chain (Hagibi et al., 2018). They are non-biodegradable as a result they continue to persist in the environment (Haoliang et al., 2007). According to researcher tolerance against heavy metals varies among mangrove species even in the same species the behaviours of metals absorption and enrichment differ at different locations (Ismail et al., 2014; Zhang et al., 2007). Excessive uptake of heavy metals by plants and its accumulation in tissues, may trigger various morphological, physiological and biochemical response (Banu and Atmaca, 2011) and may also causes a variety 
of sub-cellular activities, i.e., metabolic response that are offended at cellular phases or may prompt more extensive phototoxic reactions (Zhang et al., 2007).

In order to minimise the harmful effects of reactive oxygen species (ROS), the plants have developed their own protection mechanism, which includes nonenzymatic and enzymatic antioxidants, that play a role in scavenging ROS, (Choo et al., 2004; Ukaszewicz and Arcin, 2004). Among the antioxidants defence system ascorbate peroxidase (APX), catalyst (CAT), superoxide dismutase (SOD) and other enzymes play an important role either directly or indirectly in scavenging ROS from the plant cells (Aravind et al., 2005; Noctor, 1998). These enzymes exist in essentially all sub-cellular compartments. Normally, a cell organelle has multible enzymes that are capable to rummage a single ROS (Scandalios, 2005; Mittler et al., 2004b; 2002a). SOD is one of the widespread plant chemicals that play a crucial role in cell hindrance towards receptive oxygen organisms (ROS). Its activity changes the general proportions of free $\mathrm{O}_{2}{ }^{-}$and $\mathrm{H}_{2} \mathrm{O}_{2}$, the two Haber-Weiss reaction substrates, and decreases the risk of $\mathrm{OH}$ radical arrangement, which exceptionally opens and may make extreme disruption effect on protein and DNA (Pandey and Gaurav, 2012; Zhang et al., 2007). Stunted plant growth (shoot and root) is a very common morphological outcome when the roots systems of plants interact with soil sap including toxic heavy metals (Dalcorso et al., 2013; Omae et al., 2012). Metal toxicity result in a decrease of fresh and dry mass and fruit productivity of a plant whereas, (Rahman et al., 2010) reported reduction in a number of leaves and stunted stem heights in Kandelia candel when treated with Cd. Similarly, along with the alteration in morpho-physiological aspect; a decrease in the rate of photosynthesis and respiration process also occurred (Giri et al., 2010). Production of a lower amount of energy in the plant due to heavy metal stress consequently, causes lower rate of metabolism (Ying et al., 2010; Burton and Morgan, 1984).

However, researchers concluded that mangroves have remarkable ability to with stand high levels of heavy metal concentration, but very little evidence has been published previously regarding the physiological and biochemical processes in mangrove plants under multiple heavy metal stress (Dudani et al., 2017; Mahadavi et al., 2012; Dang et al., 2006). Therefore, it is imperative to study the tolerance strategy of mangrove plants against heavy metal for an understanding of physio- logical and biochemical response. Thus, this study was undertaken to address the following objectives:

To investigate the effect of multiple heavy metal stress on;

1) Antioxidative enzymes (ascorbate peroxidase, catalyst and superoxide dismutase) in A. marina and $R$. mucronata, leaves and roots.

2) To assess the effect of multiple heavy metals toxicity on young $A$. marina and $R$. mucronata seedlings.

\section{Materials and Methods}

Collection of propagule. $R$. mucronata propagules were collected from plants, grown at the mangrove forest site of Miani Hor stand (670 9N, 260 25E), Balochistan, Pakistan. The region is subtropical with annual rainfall (150-250 mm) during July-September. Propagules of $A$. marina were collected from the Indus delta forest near Karachi, Pakistan. The average annual temperature during winter season ranges from 11.8 to $27.8{ }^{\circ} \mathrm{C}$. For planting, only complete, undamaged propagation with unbroken testa was without emerging hypocotyls or radicles.

Rate of germination. For germination four propagules randomly planted in pots were filled with washed sand. Propagules were kept in a greenhouse under natural sunlight. Each pot was irrigated weekly using two litres of $1 / 2$ strength Hoagland solutions (Hoagland, 1950) with $10 \% \mathrm{NaCl}$ through sub-irrigation. The water level for submerged condition in each container was adjusted daily with distilled water. Seedling establishment requires the period of one month. Four months old young seedlings were treated multiple heavy metals $\mathrm{Cd}, \mathrm{Pb}$, $\mathrm{Cr}$ and $\mathrm{Hg}$ with 1/2 Hoagland's nutrient medium, ( $\mathrm{pH} \sim 6.0$ ). The multiple heavy metals containing nutrient solution were refilled after every 3 days.

Study design. A one-way complete randomized design (CRD) with three replicates per treatment was used in this study. The random samples with five independent replicates were assigned to different treatments of multiple heavy metals concentrations, namely $1 \mathrm{MHM}$, 5MHM, 10MHM, 15MHM, 20MHM.

In $1 \mathrm{MHM}$ represented $0.1 \mathrm{mg} / \mathrm{L} \mathrm{Hg}^{2+}, 1 \mathrm{mg} / \mathrm{L} \mathrm{Pb}^{2+}, 0.1$ $\mathrm{mg} / \mathrm{L} \mathrm{Cd}^{2+}$ and $0.1 \mathrm{mg} / \mathrm{L} \mathrm{Cr}^{2+}$ containing Hoagland's solution $0.5 \mathrm{MHM}$, contained $\times 5,10 \mathrm{MHM}$ contained $\times 10,15 \mathrm{MHM}$ contained $\times 15$ and $20 \mathrm{MHM}$ contained $\times 20$ time higher concentration of multiple heavy metals as compare to $1 \mathrm{MHM}$, respectively. Whereas, six sets 
of group considered as control, treated with $1 / 2$ strength of Hoagland's nutrient solution only (Hoagland and Arnon, 1950). Distilled water was added in the plastic container up to the mark to compensate the concentration of metal ions in order to balance for evapouration losses. Control (C) plants were supplemented with $2000 \mathrm{~mL}$ of $1 / 2$ strength of normal Hoagland's solution (Hoagland and Arnon, 1950).

Antioxidant enzyme extraction and assay. To measure the effect of multiple heavy metals on antioxidative enzymes activities in leaves and roots of both mangrove plants, samples were collected after every 15 days' interval till 60 days, whole plants harvested to observe SOD, CAT and APX in leaves and roots.

Sample extraction. To investigate the effect of heavy metals on enzymatic antioxidant (CAT, APX, and SOD) in leaf and root tissue was obtained from all seedlings and control seedlings of mangrove. Grind $500 \mathrm{mg}$ fresh leave and root in ice-cold potassium phosphate buffer (0.05M, pH7.0) with EDTA $(0.05 \mathrm{M})$ and $2 \%$ polyvinyl polypyrolidone (PVP). The homogenate was centrifuged at $15,000 \mathrm{rpm}$ for $15 \mathrm{~min}$ at $4{ }^{\circ} \mathrm{C}$ and the supernatant was used for the enzyme assay. Bradford methods used for estimation of protein. For standard using bovine serum albumin (Bradford, 1976).

Estimation of superoxide dismutase (SOD). Analysis of SOD activity in plant sample was estimated described by Fridovich. Set two tubes in which added $3 \mathrm{~mL}$ reaction mixture contained potassium phosphate buffer (50 mM, pH7.0 with $2 \mathrm{mM} \mathrm{EDTA),} \mathrm{Triton} \times 100(0.22 \%)$, L-methionine $(9.98 \mathrm{mM}), \mathrm{NBT}(0.058 \mathrm{mM})$, enzyme extract and lastly added riboflavin $(0.1168 \mathrm{mM})$. Place one of the sample tube in dark (used as blank), while other sample tube were exposed to light under two $20 \mathrm{~W}$ fluorescent tubes to initiate reaction. After $7 \mathrm{~min}$, incubation recorded optical density at $560 \mathrm{~nm}$ against blank.

Estimation of catalyst (CAT). In cell, hydrogen peroxide decomposed into water and oxygen due to common enzyme catalase. The activity of CAT was assayed the method of Aebi. Aebi studied in (1984) that $0.3 \mathrm{~mL}$ of reaction mixture consisted of $40 \mu \mathrm{L}$ supernatant, potassium phosphate buffer $(50 \mathrm{mM}, \mathrm{pH} 7.0)$. The reaction was initiated by addition of the $\mathrm{H}_{2} \mathrm{O}_{2}(2 \mathrm{mM}$ in phosphate buffer). The reduction of $\mathrm{H}_{2} \mathrm{O}_{2}$ was recorded at $240 \mathrm{~nm}$. APX and catalyst activity was expressed as Unit/mg protein.

Estimation of ascorbate peroxidase (APX). To record the APX activity was previously determined Nakano and Asada (1981) by monitored the optical density at $290 \mathrm{~nm} .100 \mu \mathrm{L}$ supernatant was added to reaction mixture contained $600 \mu \mathrm{L}$ potassium phosphate buffer (50 mM, pH7.0), ascorbic acid $(0.5 \mathrm{mM})$, disodium EDTA $(0.1 \mathrm{mM}), \mathrm{H}_{2} \mathrm{O}_{2}(0.1 \mathrm{mM})$.

Statistical analysis. All statistical analysis was done by two-way analysis of variance (ANOVA). The Duncan's multiple range test was using to determine the statistically significant difference between treatments at $\mathrm{P}<0.05$. All data are showed as means \pm std. error of mean (SEM) of three independent replicates of every treatment using a completely randomized design.

\section{Results and Discussion}

Operation of SOD in leaves and roots of A. marina and $R$. mucronata is significantly enhanced by multiple heavy metals (MHM) relative to control. Overall, progressive increase in the activity of SOD was observed with the increase of MHM concentration and exposure time in both plants with some variations (Fig. 1). However, response of $A$. marina and $R$. mucronata was different in terms of different concentrations and exposure duration. A. marina showed highest activity of SOD in 20MHM (6.87 U/mg protein) after 45 days of exposure in leaf tissues, whereas its roots showed highest activity after 30 days of exposure in 15MHM $(9.26 \mathrm{U} / \mathrm{mg}$ protein). At highest concentration (20MHM), the SOD activity was also higher in leaves of A. marina and in leaves of $R$. mucronata showed maximum extent of decline in activity after 60 days of exposure, while no significant loss in SOD activity was observed in control plants during these time periods. Statistical analysis stated that concentration $(\mathrm{C})$, time duration $(\mathrm{T})$ and their interaction $(\mathrm{C} \times \mathrm{T})$ showed significant $(\mathrm{P}<0.001)$ variance in roots and leaves of both species (Table 1).

A. marina and R. mucronata when treated with multiple heavy metals showed higher value of mean in CAT activity (Fig. 2) over the control. Overall, higher activity of CAT is found in 1MHM in the leaves and roots tissues of A. marina.

Between the species, the highest activity was observed in the roots of $A$. marina $38.3 \pm 1.52 \mu \mathrm{mol} / \mathrm{mg}$ protein after 15 days at $1 \mathrm{MHM}$ and the lowest activity $11.6 \pm$ $0.57 \mu \mathrm{mol} / \mathrm{mg}$ protein was observed in $R$. mucronata at 20MHM after exposure of 60 days. In A. marina the highest activity is observed in leaves at $1 \mathrm{MHM}$ (28.33 $\pm 0.5774 \mu \mathrm{mol} / \mathrm{mg}$ protein) in 45 days of treatment, whereas in $R$. mucronata the highest activity of catalase $(25.3 \pm 2.08 \mu \mathrm{mol} / \mathrm{mg}$ protein) was observed in leaves after 15 days at $1 \mathrm{MHM}$. 

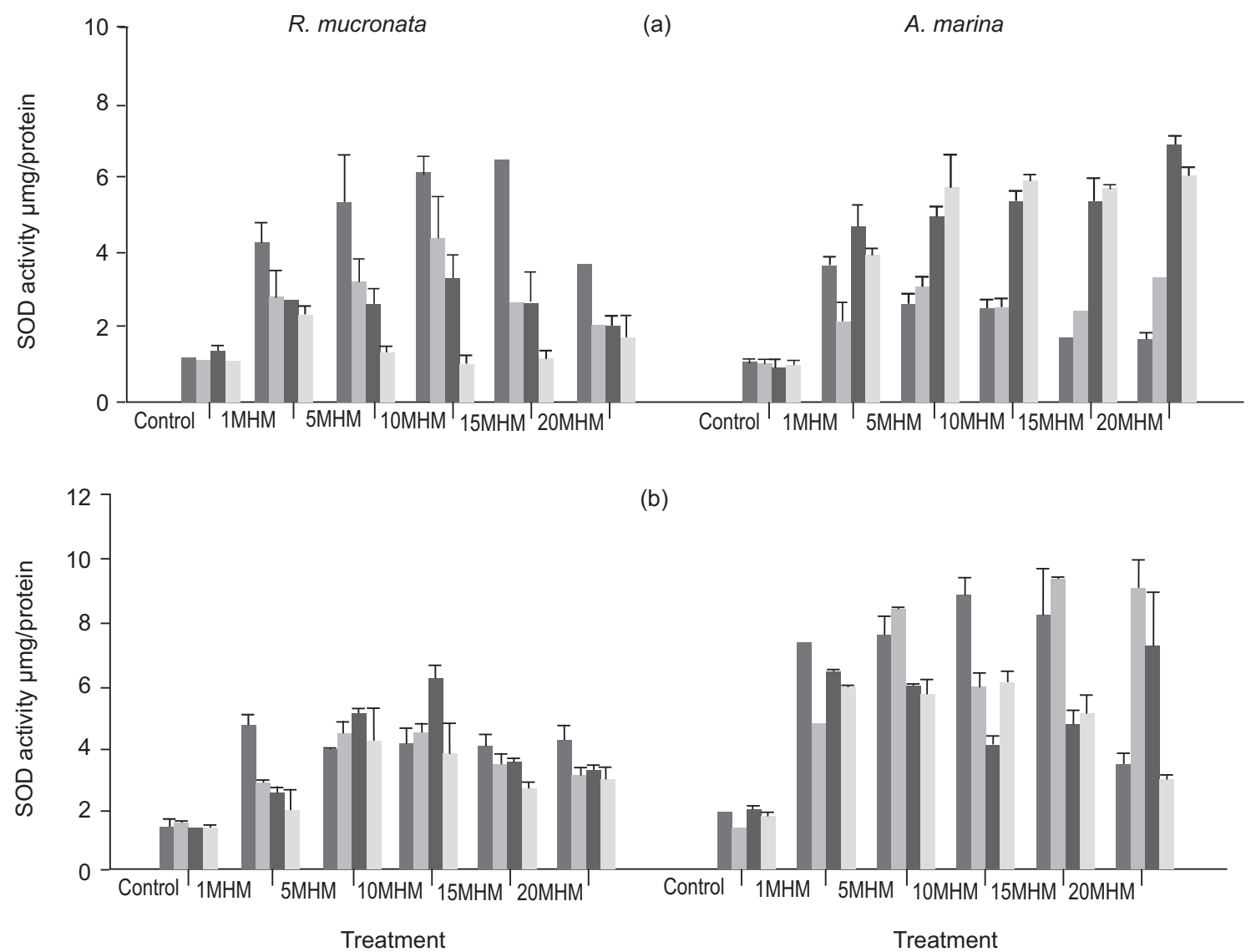

15 days $\square 30$ days $\square 45$ days $\square 60$ days

Fig. 1. Alteration in SOD activity in leaves (a) and roots (b) of two Mangroves species by different time periods $(15,30,45$ and 60 days $)$ multiple heavy metals $(n=3$, vertical bars represent \pm SE.

Table 1. Two-way ANOVA (Duncan's Multiple Range Test) indicating effect of different multiple heavy metal concentration $(\mathrm{C})$, time duration $(\mathrm{T})$ and their interactions $(\mathrm{C} \times \mathrm{T})$, from catalase $(\mathrm{CAT})$, ascorbate peroxidase (APX), superoxide dismutase (SOD) of $A$. marina and $R$. mucronata and $\mathrm{df}=$ Degree of freedom

\begin{tabular}{|c|c|c|c|c|c|c|c|}
\hline \multirow{2}{*}{$\begin{array}{l}\text { A. marina } \\
\text { Factors }\end{array}$} & \multirow[b]{2}{*}{$\mathrm{DF}$} & \multicolumn{3}{|c|}{ Leaves } & \multicolumn{3}{|c|}{ Roots } \\
\hline & & CAT & APX & SOD & CAT & APX & SOD \\
\hline Concentration (C) & 5 & $199 * * *$ & $85 * * *$ & $146^{* * *}$ & $132 * * *$ & $220 * * *$ & $125 * * *$ \\
\hline Time duration $(\mathrm{T})$ & 3 & $13.9 * * *$ & $55^{* * *}$ & $258 * * *$ & $44.1 * * *$ & $45.3 * * *$ & $43.4 * * *$ \\
\hline $\mathrm{C} \times \mathrm{T}$ & 15 & $3.99 * * *$ & $9.43 * * *$ & $23.01 * * *$ & $3.96 * * *$ & $14.66^{* * *}$ & $27.23 * * *$ \\
\hline Error & 48 & & & & & & \\
\hline \multicolumn{2}{|l|}{ R. mucronata } & \multicolumn{3}{|c|}{ Leaves } & \multicolumn{3}{|c|}{ Roots } \\
\hline Factors & DF & CAT & APX & SOD & CAT & APX & SOD \\
\hline Concentration (C) & 5 & $90.36 * * *$ & $36.73 * * *$ & $38.69 * * *$ & $33.54 * * *$ & $41.54 * * *$ & $140.22 * * *$ \\
\hline Time duration $(\mathrm{T})$ & 3 & $128 * * *$ & $58.77 * * *$ & $126.75 * * *$ & $29.31 * * *$ & $84 * * *$ & $27.11 * * *$ \\
\hline $\mathrm{C} \times \mathrm{T}$ & 15 & $8.63 * * *$ & $5.57 * * *$ & $10.11 * * *$ & $1.239^{\mathrm{ns}}$ & $3.37 * * *$ & $13.16^{* * *}$ \\
\hline Error & 48 & & & & & & \\
\hline
\end{tabular}

*** = significant at $<0.001 ; \mathrm{ns}=$ non-significant confidence levels, respectively. 
The highest value that was $31 \pm 1.0 \mu \mathrm{mol} / \mathrm{mg}$ protein was observed in roots of $R$. mucronata at $1 \mathrm{MHM}$ after 30 days of metals treatment. Statistical analysis expressed that concentration $(\mathrm{C})$, time duration $(\mathrm{T})$ and their interaction $(\mathrm{C} \times \mathrm{T})$ were significant $(\mathrm{P}<0.001)$ differences in CAT at both parts (roots and leaves) of $A$. marina and in roots did not show significant variance in roots of R. mucronata (Table 1).

The overall APX activity in both species showed an increasing trend due to MHM stress in reference of control (Fig. 3). Comparatively, A. marina showed higher APX activity than R. mucronata in both leaves and roots. The highest activity in leaves was recorded $19.130 \pm 0.19 \mu \mathrm{mol} / \mathrm{mg}$ protein $/ \mathrm{min}$ in $20 \mathrm{MHM}$ after 30 days of multiple metals stress, where as in roots, it was recorded $19.02 \pm 0.087 \mu \mathrm{mol} / \mathrm{mg}$ protein $/ \mathrm{min}$ in $10 \mathrm{MHM}$ after 30 days' period. In $R$. mucronata, the highest values in leaves found $9.35 \pm 0.92 \mu \mathrm{l} / \mathrm{mg}$ protein $/ \mathrm{min}$ after 15 days at $5 \mathrm{MHM}$ and in roots the higher activity was recorded $12.7 \pm 0.49 \mu \mathrm{mol} / \mathrm{mg}$ protein $/ \mathrm{min}$ at $10 \mathrm{MHM}$ after 15 days of treatment. Statistical analysis expressed that concentration $(\mathrm{C})$, time duration $(\mathrm{T})$ and their interaction $(\mathrm{C} \times \mathrm{T})$ indicated highly significant $(\mathrm{P}<0.001)$ differences in APX at both parts (roots and leaves) of mangrove (Table 1).

In this research, response of $A$. marina and $R$. mucronata were evaluated against induced multiple heavy metals stress such as cadmium, chromium, lead and mercury. The results show increased antioxidant activities in both species, with the exposure of heavy metals reflecting a damage response to stress factors in mangrove species. The activation of CAT, APX and SOD are an essential protective mechanism to reduce oxidative injury in Mangrove plants when exposed to multiple heavy

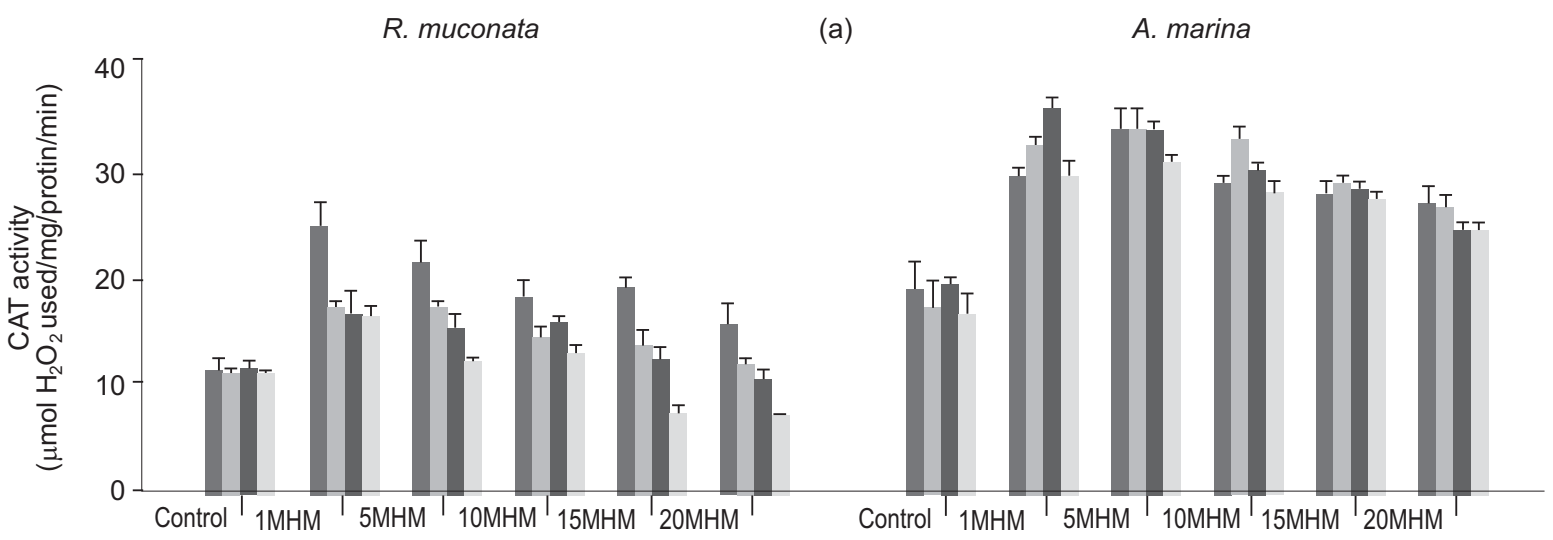

(b)

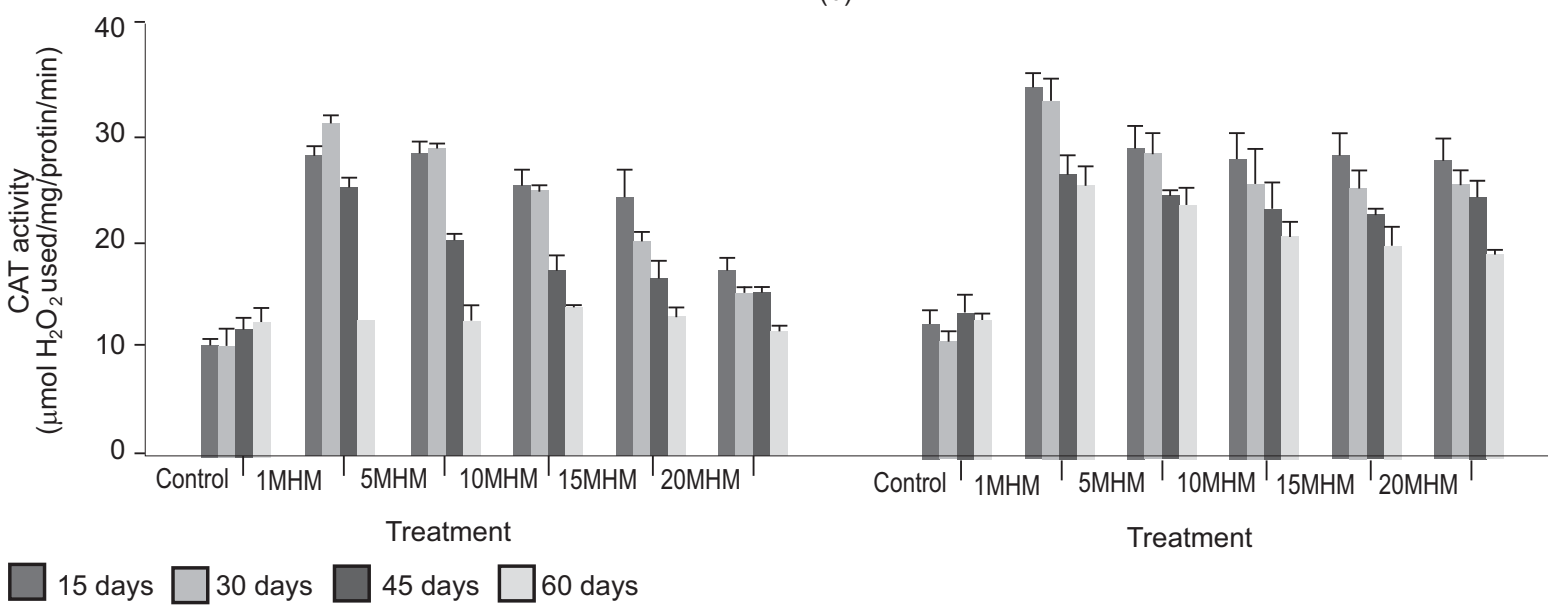

Fig. 2. Alteration in CAT activity in leaves (a) and roots (b) of two Mangroves species by different time periods $(15,30,45$ and 60 days $)$ multiple heavy metals $(n=3$, vertical bars represent $\pm S E)$. 
metals. All three antioxidant enzymes (SOD, APX and CAT) were significantly higher in A. marina compared to $R$. mucronata. There is also a marked difference in the antioxidants activities in root and leaves tissues of both the species, however, the disparity was more distinct in A. marina indicating that grey mangrove has an efficient antioxidant system.

SOD is the primary antioxidant enzyme that performing in living organisms, as a superoxide radical dismutation into oxygen and $\mathrm{H}_{2} \mathrm{O}_{2}$ (Zayneb et al., 2015). Our investigation showed that SOD enzyme balances the ROS in all concentration levels in leaves and roots throughout the time period of stress from 15 days to 60 days. In leaves of $A$. marina, high SOD activity was observed in prolonged exposure that is 45 and 60 days of interval, whereas an opposite trend was observed in the leaves of $R$. mucronata (Fig. 1). In SOD activity with high concentration of multiple heavy metals and their prolonged exposure, indicating that the oxygen scavenging function of SOD was impaired. These findings are in agreement with the results of Alyssum species and Allium sativum (Zhang et al., 2007; Schckler and Caspi, 1999). SOD activity in roots of A. marina peaked at higher metal concentrations than in of R. mucronata and the response of A. marina was more pronounced, suggesting that increase in SOD has better protection against oxidant damage (Takemura et al., 2000; Bowler et al., 1992).

For most living cells catalase is ubiquitous, which plays an oxidative catalyst and serves as a main enzyme necessary for ROS detoxification in plants. CAT removes $\mathrm{H}_{2} \mathrm{O}_{2}$ by decomposing it, into water and oxygen (Lin and Kao, 2000). According to our results, there is enhancement of CAT activity in both species of
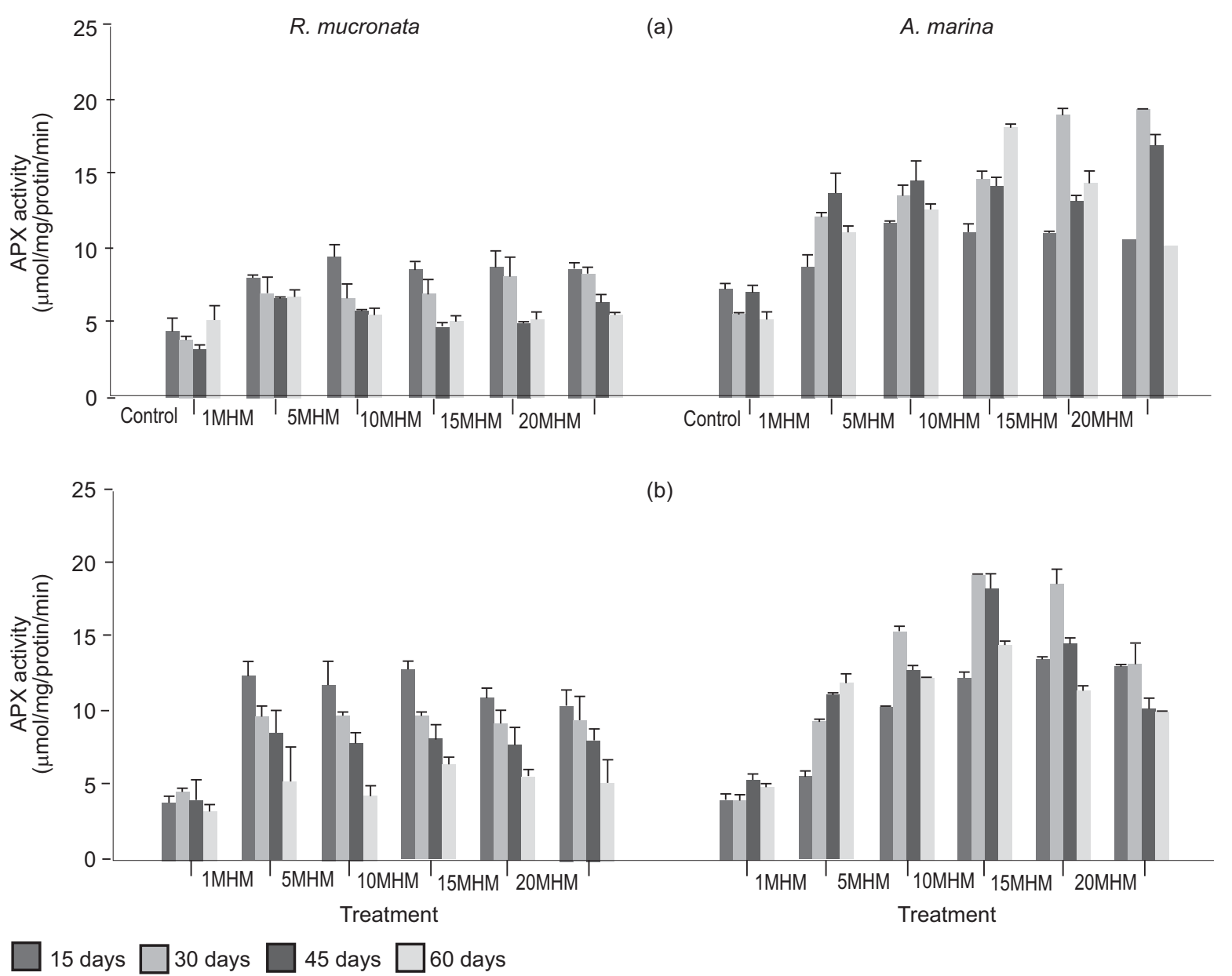

Fig. 3. Alteration in APX activity in leaves (a) and roots (b) of two Mangroves species by different time periods $(15,30,45$ and 60 days) multiple heavy metals $(n=3$, vertical bars represent $\pm S E)$. 
mangroves and the catalase activity is a good symbol for reducing cellular damage via lower $\mathrm{H}_{2} \mathrm{O}_{2}$ level (Sakmen et al., 2007; Witlekens et al., 1995). Similar trend were reported under multiple heavy metals stress in two months old Kandelia candel (Huang et al., 2010). Different researchers have also confirmed that various antioxidants defences in mangroves are elicited comprising SOD, APX and CAT under abiotic stress. (Hossain et al., 2010; Jithesh et al., 2006; Takemura et al., 2000). Same result was also observed at different concentrations (control, 100 mM, 200 mM, 300 mM) of induced $\mathrm{Zn}$ in finger millet at different days of seedling growth (Gonr and Srivastava, 2018).

In $R$. mucronata, CAT activity was higher in roots then leaves, and higher activity $(38.3 \pm 1.52 \mu \mathrm{mol} / \mathrm{mg}$ proteins were observed after 15 days' interval. In A. marina, CAT activity was overall increased in both leaves and roots tissues under heavy metals stress in different interval of time. The higher SOD and CAT activities in A. marina signifies that the $\mathrm{H}_{2} \mathrm{O}_{2}$ scavenging strategy is more efficient than in $R$. mucronata, since CAT activity synchronized with SOD activity play a very important protective role in the $\mathrm{O}_{2}$ and $\mathrm{H}_{2} \mathrm{O}_{2}$ scavenging process (Badawi et al., 2004; Liang et al., 2003). Hence, our results imply that $A$. marina may be more tolerant to heavy metals.

APX is one of the main enzymes for scavenging the poisonous $\mathrm{H}_{2} \mathrm{O}_{2}$ from the cell, which is widely, distributed antioxidant found in plants (Huang et al., 2010; Noctor, 1998). In the current study, APX depicts a trend with initial increase and following decline in response to increment in metal dose level (Fig.3). This shows conformity with previous studies about the APX activities in different plants including mangroves. Enhancement of APX activities were also observed in roots and leaves tissues of both the species which advocates an augment in $\mathrm{H}_{2} \mathrm{O}_{2}$ amount and their involvement in its removal from the two species via AsA-GSH cycle (Yamane et al., 2010; Liu, 2007; Karam and Teixeira, 2006; Singh et al., 2006) and this shows that induction of defence mechanism adapted by plants in stress environment (Yamane et al., 2010; Zhang et al., 2007). Whereas (Kisa, 2018; Aghaei et al., 2009; Gallego et al., 1996) recorded decreased APX activity in plants under various development stage. APX activities in the roots of $A$. marina and $R$. mucronata, increased to their respective control levels which shows similarity with Kandelia candel and dis-similarity with Bruguiera gymnorrhiza (Zhang et al., 2007).

It is worth mentioning that the SOD, CAT and APX to most response towards the treatments against MHM stress also varies with a dose-exposure period. In the case of a dose-exposure experiment under MHM tension, results (Fig 1, 2, 3 and Table 1) reveal that both of the species behaved differently. A. marina appeared to with hold the MHM stress for longer period of time then $R$. mucronata at different time periods. It may be a plant endured at one period may be sensitive at other period. It is also explained by (Maksymiec, 2007) that plant varies in response against exposure time of heavy metals and this variation may depict that $\mathrm{H}_{2} \mathrm{O}_{2}$ accrual developed in a different way during a long stress action, however exact mechanism is not yet known. On the other hand, studies reveal that CAT, SOD and APX activity increases as a first effect of heavy metals due to the increased NADPH oxidase activity and after a longer time decrease in the activity was observed which is connected with attenuation of the enzymatic antioxidative system and increment in the peroxidation of lipids (Maksymiec, 2007; Sandalio et al., 2001).

In any case, oxidative stress was established to be obligatory in every heavy metal-treated samples manifest in the course of rising amounts of $\mathrm{H}_{2} \mathrm{O}_{2}$, with biochemical verification for this induction being supply via up regulated action of main ROS metabolizing enzymes such as SOD, CAT and APX. Dismutation of superoxide radicals to $\mathrm{H}_{2} \mathrm{O}_{2}$ is done by $\mathrm{SOD}$, while CAT and APX act as $\mathrm{H}_{2} \mathrm{O}_{2}$ scavengers (Gill and Tuteja, 2010). Current findings in mangroves (A. marina and $R$. mucronata) are line with numerous other reports which confirmed up-regulated enzymatic activity of SOD, CAT and APX, in tomato, watercress, sunflower (Duman and Fatma, 2010; Chaboute et al., 2009; Choudhary et al., 2007) signifying the occurrence of a ROS scavenging mechanism in an endeavour of the plants to guard themselves (Georgiadou, 2018). However, in the present study the combined effect of MHM investigated in two different mangroves species which are dominant in Pakistan that ultimately signifies the scavenging activity of ROS.

\section{Conclusion}

The outcome of the present investigation clearly concluded that two mangroves species Avicennia marina \& Rhizophora mucronata exhibit distinct variation of 
enzymatic antioxidant level when exposed to multiple heavy metals stress during different periods. Nevertheless, in leaves and roots of both the plants, there is synchronised increase in SOD, CAT, APX activities for scavenging the toxic metals. A. marina compared to $R$. mucronata, has more tendency as antioxidative defence, to adapt to the oxidative stress induced by heavy metal toxicity as a metal tolerant mangrove species.

\section{Acknowledgment}

We are thankful to WWF of Pakistan for providing propagules of the mangrove species. We are also thankful to Dr. Muhammad Uzair and Dr. Kanwal Nazim for review of the manuscript and their valuable suggestions.

Conflict of Interest. The authors declare no conflict of interest.

\section{References}

Aebi, H. 1984. Catalase in vitro. Methods Enzymology, 105: 121-126.

Aghaei, K., Ehsanpour, A., Shah, A. 2009. Proteome analysis of soybean hypocotyl and root under salt stress. Amino Acid, 36: 91-98.

Alongi, D.M., Dixon, P. 2000. Mangrove primary production and above and below-ground biomass in sawi bay, southern Thailand. Phuket Marine Biological Center Special Publication, 22: 31-38.

Aravind, P., Narasimha, M., Prasad, V. 2005. Modulation of cadmium induced oxidative stress in Ceratophyllum demersum by zinc involves ascorbateglutathione cycle and glutathione metabolism. Plant Physiology and Biochemistry, 43: 107-116.

Badawi, G., Yamauchi, Y., Shimada, E., Sasaki, R., Kawano, N.,Tanaka, K. 2004. Enhanced tolerance to salt stress and water deficit by over expressing superoxide dismutase in tobacco (Nicotiana tabacum) chloroplast. Plant Science, 166: 919-928.

Banu, Z., Atmaca, M. 2011. Influence of airborne pollution on $\mathrm{Cd}, \mathrm{Zn}, \mathrm{Pb}, \mathrm{Cu}$, and $\mathrm{Al}$ accumulation and physiological parameters of plant leaves in Antakya (Turkey). Water Air Soil Pollution, 214: 509-523.

Bowler, C., Montagu,V., Inze, D. 1992. Superoxide dismutase and stress tolerance. Physiology and Molecular Biology of Plants, 43: 83-116.

Bradford, M.M. 1976. A rapid and sensitive method for the quantitation microgram quantities of protein utilizing the principle of protein dye binding.
Analytical Biochemistry, 72: 248-254.

Burton, K.W., Morgan, E. 1984. The influce of heavy metal upon the growth of sitka-spruce in south wales forests. Plant and Soil, 78: 271-282.

Chaboute, M., Guy, H., Fatma, J. 2009. Cadmium and copper induction of oxidative stress and antioxidative response in tomato (Solanum lycopersicon) leaves. Plant Growth Regulation, 57: 89-99.

Choo, K., Pauli, S., Marianne, P. 2004. Oxidative stress tolerance in the filamentous green algae Cladophora glomerata and Enteromorpha ahlneriana. Journal of Experimental Marine Biology and Ecology, 298: 111-123.

Choudhary, M., Jetley, U., Khan, M., Zutshi, S. 2007. Effect of heavy metal stress on proline, malondialdehyde, and superoxide dismutase activity in the Cyanobacterium spirulina platensis -s 5 . Ecotoxicology and Environmental Safety, 66: 204209.

Dalcorso, G., Fasani, E., Furini, A. 2013. Recent advances in the analysis of metal hyper accu-mulation and hypertolerance in plants using proteomics. Frontiers in Plant Science, 4: 280-310.

Dang, T.C., Bayen, S., Wurl, O., Obbard, J. Karuppiah, S., Wong, K. 2006. Heavy metal contamination in Mangrove habitats of singapore persistent organic pollutants in mangrove food webs in singapore. Chemosphere, 61: 303-313.

Dudani, S.N., Lakhmapurkar, J.,Gavali, D., Patel, T. 2017. Heavy metal accumulation in the mangrove ecosystem of south Gujarat coast, India. Turkish Journal of Fisheries and Aquatic Sciences, 17: 755-766.

Duman, F., Fatma, O. 2010. Nickel accumulation and its effect on biomass, protein content and antioxidative enzymes in roots and leaves of watercress (Nasturtium officinale R. Br.). Journal of Environmental Sciences, 22: 526-232.

Fridovich, I., Beyer, W. 1987. Assaying for superoxide dismutase activity: some large consequences of minor changes in conditions. Analytical Biochemistry, 161: 559-566.

Gallego, S., Benavides, M., Tomaro, M. 1996. Effect of heavy metal ion excess on sunflower leaves: evidence for involvement of oxidative stress. Plant Science, 121: 151-159.

Georgiadou, E. 2018. Influence of heavy metals (Ni, $\mathrm{Cu}$, and $\mathrm{Zn}$ ) on nitro-oxidative stress responses, proteome regulation and allergen production in basil (Ocimum basilicum L.) Plants. Frontiers in 
Plant Science, 9: 1-16.

Gill, S.S., Tuteja, N. 2010. Reactive oxygen species and antioxidant machinery in abiotic stress tolerance in crop plants. Plant Physiology and Biochemistry, 48: 909-930.

Giri, C., Larry, L.T., Zhu, Z., Singh, A., Loveland, T., Masek, J., Duke, N. 2010. Status and distribution of mangrove forests of the world using earth observation satellite data. Global Ecology and Biogeography, 20: 154-159.

Gonr, M., Srivastava, M. 2018. Effect of zinc stress on antioxidant defense system of finger millet. International Journal of Botany Studies, 3: 80-83.

Hagibi, A., Selwi, A., Nagi, Shwafi, N. 2018. Study of heavy metals contamination in mangrove sediments of the Red sea coast of Yemen from Al-salif to Bab-el-Mandeb strait. Journal of Ecology and Natural Resources, 2: 2578-2584.

Haoliang, L., Chongling, Y., Jingchun, L. 2007. Lowmolecular-weight organic acids exuded by mangrove (Kandelia candel L.) Druce, roots and their effect on cadmium species change in the rhizosphere. Environmental and Experimental Botany, 61: 159-166.

Hatata, M.M., Abdel, M. 2008. Oxidative stress and antioxidant defense mechanisms in response to cadmium treatments. American-Eurasian Journal of Agricultural and Environmental Science, 4: 655669.

Hoagland, D.R., Arnon, D.I. 1950. The water-culture method for growing plants without soil. Proceedings of the American Society for Horticultural Science, 30: $288-294$.

Hossain, M.A., Hasanuzzaman, M., Fujita, M. 2010. Up-regulation of antioxidant and glyoxalase systems by exogenous glycinebetaine and proline in Mung bean confer tolerance to cadmium stress. Physiology and Molecular Biology of Plants, 16: 259-272.

Huang, G.Y., Wang, Y., Sun, C.S., Dong, J. 2010. The effect of multiple heavy metals on ascorbate, glutathione and related enzymes in two mangrove plant seedlings (Kandelia candel and Bruguiera gymnorrhiza). International Journal of Oceanography and Hydrobiology, 1: 11-25.

Ismail, S., Saifullah, S., Khan, S. 2014. Bio-geochemical studies of indus delta mangrove ecosystem through heavy metal assessment. Pakistan Journal of Botany, 46: 1277-1285.

Jithesh, M.N., Prashanth, S., Sivaprakash, K.R., Ajay, K. 2006. Antioxidative response mechanisms in halophytes. Journal of Genetics, 85: 237-254.

Karam, F., Teixeira, E.L. 2006. Rice ascorbate peroxidase gene family encodes functionally diverse isoforms localized in different subcellular compartments. Planta, 224: 300-314.

Kisa, D. 2018. The responses of antioxidant system against the heavy metal induced stress in tomato. Journal of Natural and Applied Sciences, 22: 1-6.

Liang,Y., Chen, Q., Zhang, W., Ding, R. 2003. Exogenous silicon $(\mathrm{Si})$ increases antioxidant enzyme activity and reduces lipid peroxidation in roots of salt-stressed barley (Hordeum vulgare L.). Journal of Plant Physiology, 160: 1157-1164.

Lin, C.C., Kao, C.H. 2000. Effect of $\mathrm{NaCl}$ stress on $\mathrm{H}_{2} \mathrm{O}_{2}$ metabolism in rice leaves. Plant Growth Regulation, 30: 151-155.

Liu, Y. 2007. Cadmium induced oxidative stress and response of the ascorbate-glutathione cycle in Bechmeria nivea (L.) Gaud. Chemosphere, 69: 99107.

Mahdavi, S., Rahimi, K., Vakili, A. 2012. Pb and Cd accumulation in Avicennia marina from Qeshm island, persian Gulf. Iranian Journal of Fisheries Sciences, 11: 867-875.

Maksymiec, W. 2007. Signaling responses in plants to heavy metal stress. Acta Physiologiae Plantarum, 29: 177-187.

Mittler, R. 2002a. Oxidative stress antioxidants and stress tolerance. Trends in Plant Science, 7: 405410.

Mittler, R., Vanderauwera, M.G., Frank, B. 2004b. Reactive oxygen gene network of plants. Abiotic Stress Series, 9: 490-498.

Nakano, Y., Asada, K. 1981. Hydrogen peroxide is scavenged by ascorbate specific peroxidase in spinach chloroplasts. Plant and Cell Physiology, 22: $867-880$.

Noctor, G. 1998. Ascorbate and glutathione: keeping active oxygen under control. Physiology and Molecular Biology of Plants, 49: 249-279.

Omae, H., Kumar, A., Shono, M. 2012. Adaptation to high temperature and water deficit in the common bean (Phaseolus vulgaris L.) during the reproductive period. Journal of Botany, 10: 1-10.

Pandey, N., Gaurav, K.S. 2012. Studies on antioxidative enzymes induced by cadmium in pea plants (Pisum sativum). Journal of Environmental Biology, 33: 201-206.

Rahman, M.M., Rahman, M., Chongling, Y., Islam, K. 2010. Changes in growth and antioxidant enzyme 
activities during cadmium stress in the mangrove plant Kandelia candel (L.) Druce. Advances in Environmental Sciences, 2: 15-24.

Sandalio, L.M., Dalurzo, H., Gomez, M. 2001. Cadmium induced changes in the growth and oxidative metabolism of pea plants. Journal of Experimental Botany, 52: 2115-2126.

Scandalios, J.G. 2005. Oxidative stress: Molecular perception and transduction of signals triggering antioxidant gene defenses. Brazilian Journal of Medical and Biological Research, 38: 995-1014.

Schickler, H., Caspi, H. 1999. Response of antioxidative enzymes to nickel and cadmium stress in hyperaccumulator plants of the genus alyssum. Physiologia Plantarum, 105: 39-44.

Sekmen, A., Türkan, I., Takio, S. 2007. Differential responses of antioxidative enzymes and lipid peroxidation to salt stress in salt-tolerant Plantago maritime and salt-sensitive. Plantago media. Physiologia Plantarum, 131: 399-411.

Singh, S., Eapen, S., DSouza, S. 2006. Cadmium accumulation and its influence on lipid peroxidation and antioxidative system in an aquatic plant, Bacopa monnieri L., Chemosphere, 62: 233-246.

Takemura, T., Hanagata, N., Sugihara, K., Baba, S., Karube, I., Dubinsky, Z. 2000. Physiological and biochemical responses to salt stress in the mangrove, Bruguiera gymnorrhiza. Aquatic Botany, 68: 15-28.
Ukaszewicz, M., Arcin, L. 2004. Antioxidant capacity manipulation in transgenic potato tuber by changes in phenolic compounds content. Journal of Agricultural and Food Chemistry, 52: 1526-1533.

Witlekens, H., Inz, D., Montagu, V.M., Camp, W. 1995. Catalases in plants. Molecular Breeding, 1: 207228.

Yamane, K., Mitsuya, S., Taniguchi, M., Miyaka, H. 2010. Transcription profiles of genes encoding catalase and ascorbate peroxidase in the rice leaf tissues under salinity. Plant Production Sciences, 13: 164-168.

Ying, R.R., Qiu, R., Tang, Y., Hu, P., Qiu, H., Chen, H., Shi, H.T., Morel, J. 2010. Cadmium tolerance of carbon assimilation enzymes and chloroplast in $\mathrm{Zn} / \mathrm{Cd}$ hyperaccumulator Picris divaricata. Journal of Plant Physiology, 2: 81-87.

Zayneb, C., Bassem, K., Zeineb, K., Grubb, C., Noureddine, D., Hafedh, M., Amine, E. 2015. Physiological responses of Fenugreek seedlings and plants treated with cadmium. Environmental Science and Pollution Research, 22: 10679-10689.

Zhang, F., Wang, Y., Lou, Z., Dong, J. 2007. Effect of heavy metal stress on antioxidative enzymes and lipid peroxidation in leaves and roots of two mangrove plant seedlings (Kandelia candel and Bruguiera gymnorrhiza). Chemosphere, 67: 44-50. 